\title{
Morphological and immunohistochemical study of testicular capsule and peritubular tissue of emu (Dromaius novaehollandiae) and ostrich (Struthio camelus)
}

\author{
P. C. Ozegbe \& T. A. Aire \& M.-C. Madekurozwa \& \\ J. T. Soley \\ P. C. Ozegbe : T. A. Aire : M.-C. Madekurozwa : J. T. Soley \\ Department of Anatomy and Physiology, \\ Faculty of Veterinary Science, University of Pretoria, \\ Onderstepoort 0110, South Africa \\ Present address: \\ T. A. Aire \\ Department of Preclinical Veterinary Studies, \\ School of Veterinary Medicine, St. George's University, \\ True Blue, Grenada, West Indies \\ e-mail: taire@sgu.edu
}

The authors are grateful for a University of Pretoria research grant, which aided this work. Dr Peter Ozegbe of the Department of Veterinary Anatomy, University of Ibadan is a recipient of the University of Pretoria Foreign Post-Doctoral Fellowship.

With 4 figures 1 table

\begin{abstract}
The testicular capsule and peritubular boundary tissue of the emu and ostrich, as typical representatives of ratite birds, were studied in sexually mature and active birds.

The testicular capsule was much thicker $(578.1 \pm 73.4 \mu \mathrm{m}$ for the free surface of the ostrich testis, and $176.2 \pm 57.5 \mu \mathrm{mfor}$ the emu) than those of members of the Galloanserae. The cellular composition of both testicular capsule and peritubular tissue was similar generally to that of members of the previously studied Galloanserae and of mammals. The tunica albuginea of the testicular capsule mainly comprised smooth-musclelike or myoid cells mostly running in one direction and occurring in one main mass. Unlike the Galloanserae, the tunica albuginea contained more collagen fibres than smooth muscle cells, especially in the ostrich. Peritubular tissue was similarly composed of smooth-muscle-like cells distributed in several layers. Actin microfilaments and desmin and vimentin intermediate filaments were variably immunoexpressed in these two tissue types in both birds, with a clear dichotomy in the peritubular tissue. Thus, taken together with studies of some members of the Galloanserae, avian testes clearly contain a morphological mechanism that is represented partly by the smooth muscle cells of the testicular capsule and peritubular tissue for transporting the testicular fluid, which is usually copious in birds, and its cellular content from the testis into the excurrent duct system; thismechanism is similar to that found in mammals.
\end{abstract}

Keywords Testicular capsule . Peritubular tissue . Structure . Intermediate filaments . Immunohistochemistry . Emu (Dromaius novaehollandiae) .

Ostrich (Struthio camelus) (Aves, Ratitae)

\section{Introduction}

The testicular capsule is now widely regarded as an important component of the contractile, forward sperm-propelling mechanism of the testis (Hargrove et al. 1977; Middendorff et al. 2002; Banks et al. 2006). The contractile cells, which, on account of their cytoplasmic filament content, have been regarded as myoid (myofibroblast) cells (Leeson and Forman 1981) or genuine smooth muscle cells (Langford and Heller 1973), have been observed in this tissue in several mammalian species (Davis et al. 1970; Holstein 1967; Holstein and Weiss 1967; Hargrove et al. 1977; Middendorff et al. 2002; Banks et al. 2006). 
Immunohistochemical studies of these contractile cells in the testicular capsule, in some mammals, have shown that they contain a number of microfilaments (MF) and

intermediate filaments (IF), such as actin (Santamaria et al. 1990; Maekawa et al. 1991), smooth muscle myosin and desmin (Paranko and Pelliniemi 1992) and vimentin, desmin, a-smooth muscle actin and smooth muscle myosin (Middendorff et al. 2002).

Seminiferous tubules in all mammals are surrounded by boundary tissue that contains myoid or smooth muscle cells (Maekawa et al. 1996). The cytoskeletal content of these cells, in mammals, includes $\alpha$-smooth muscle actin, desmin and vimentin (Virtanen et al. 1986; Steger and Wrobel 1994; Wrobel et al. 1995; Maekawa et al. 1996).

The morphology of the testicular capsule and peritubular boundary tissue of birds have received attention that can be only described as poor, especially for a class of animals as large as Aves, whose members have intra-abdominal testes that secrete a large quantity of testicular fluid and whose spermatogenesis and sperm transport are rapid compared with those of mammals (Aire 2007a, 2007b). Whereas the peritubular tissue has been studied in merely a few birds (Rothwell and Tingari 1973; Aire 1997), even less is known of the contractile cells and their cytoskeletal content. Only a few recent reports exist on the characterization of the MF and IF content of possible myoid or smooth muscle cells in the testicular capsule and peritubular tissue of the quail (Van Nassauw et al. 1993), domestic fowl (Maretta and Marettova 2004) and four members of the Galloanserae (Aire and Ozegbe 2007).

The purpose of this paper is to contribute to and complement knowledge of the structure of the testicular capsule and peritubular boundary tissue in two members (emu and ostrich) of a primitive group of birds, which belong to the family Ratitae. Histological, ultrastructural and immunohistochemical techniques have been employed in the study of these tissues in these birds.

\section{Materials and methods}

The tissues used in this study were obtained from birds that were slaughtered in an ostrich abattoir, near Pretoria. Pieces of testicular capsule and parenchyma tissue of adult, sexually active, male ostrich $(n=5)$ and emus $(n=5)$ were immersion-fixed in either $4 \%$ glutaraldehyde in Millonig's phosphate buffer or $10 \%$ buffered formalin or Bouin's fluid. The tissue blocks were subsequently processed by conventional standard procedures for light and electron microscopy. For electron microscopy, the fixed tissue blocks were postfixed in osmium tetroxide for $1 \mathrm{~h}$, and subsequently dehydrated through a graded series of ethanol. The blocks were, thereafter, embedded in Epon. Thick sections were cut in a Porter-Blum MT-2B ultramicrotome, stained with toluidine blue and examined in the light microscope. Ultrathin sections of appropriate areas were cut from the tissue blocks, stained with uranyl acetate and lead citrate, and examined in a Jeol $100 \mathrm{CX}$ transmission electron microscope.

\section{Histology and morphometry}

Tissues fixed in Bouin's fluid or formalin-fixed tissues were processed and embedded in paraffin wax, sectionedmicroscopy. The thickness of the testicular capsule of each bird was measured by using a calibrated eye-piece micrometer. Measurements were taken on both free surfaces and the orchido-epididymal border. Within bird differences between measurements for the free surface and orchidoepididymal border and between bird differences for these parameters were evaluated by Student's t-test; the significance level was set at $1 \%$.

\section{Immunohistochemistry}

For the immunohistochemical examination, selected formalinfixed tissue sections, mounted on slides pre-coated with polylysine, were deparaffinized and treated with $3 \%$ hydrogen peroxide to inhibit endogenous peroxidase. After non-specific reaction had been blocked, the sections were subsequently microwaved at $750 \mathrm{~W}$ for two cycles of 7 min each in citrate buffer ( $\mathrm{pH} 6)$. Thereafter, the sections were allowed to cool at room temperature, for $20 \mathrm{~min}$, before being rinsed in phosphate-buffered saline (PBS) containing bovine serum 
albumin ( $\mathrm{pH} 7.6)$, for $5 \mathrm{~min}$. Subsequently, the sections were incubated with the specific primary antibody for $30 \mathrm{~min}$, following the protocol of LSAB+ kit (DakoCytomation, Denmark). The antibodies used were against smooth muscle actin (M085101; diluted 1:50), cytokeratin (M082101; 1: 100), desmin (A0611; 1:300) and vimentin (M072501; 1:100). After being rinsed in PBS, each slide was incubated for 15 min in a link antibody (biotinylated secondary antibody) and then peroxidase-labelled streptavidin. Antigen localization was visualized by incubation of the sections with either the 3,3- diaminobenzidine (DAB) of the LSAB+ kit (emu) or VECTOR NovaRED (ostrich) solutions. The sections were counterstained with haematoxylin.

\section{Results}

\section{Morphometry, histology and ultrastructure}

\section{Testicular capsule}

The thickness of the testicular capsule of each bird is as shown in Table 1. The ostrich capsule is over three times thicker than that of the emu, on the free surface, and the epididymotesticular/ orchido-epididymal interface is about four times thicker in the ostrich than that in the emu.

The testicular capsule is composed of three main layers of tissue, viz. the tunica serosa, tunica albuginea and tunica vasculosa (Fig. 1). The tunica serosa forms a single layer of flattened mesothelial cells, whose nuclei are considerably elongated and heterochromatic. This cell layer lies on a basement membrane, which, in turn, is supported by a layer of amorphous tissue (inset in Fig. 1).

The tunica albuginea is the main tissue layer and comprises cellular elements that alternate with thick bundles of collagen fibres that are oriented variably in all directions. The cell content of the tunica albuginea is mainly of one type and is considered to be myoid or smooth muscle cell, each of which runs in a parallel direction to its fellows and contains a usually elongated, moderately euchromatic nucleus. Each of the smooth muscle cells in the outer zone of the tunica albuginea arborizes and encloses voluminous bundles of collagen (inset in Fig. 1). The inner zone is comprised mainly of smooth muscle cells in the emu (Fig. 2). The distribution of both smooth muscle cells and collagen in the ostrich is relatively uniform throughout the tunica albuginea, unlike in the emu. However, the ostrich shows a much greater concentration of collagen bundles in this tunic than is found in the emu (Fig. 2). The cytoplasm of each of the myoid cells contains an abundance of MFs that run in parallel bundles, along the length of the cell. The cell cytoplasm arborizes considerably, sending cytoplasmic processes that also run longitudinally and seem to enclose bundles of collagen fibres. Such sleeves of cytoplasm are better developed in the ostrich than in the emu. Cytoplasmic organelles, which are generally confined to the central part of the cell by the MFs, include scattered short strands of rough endoplasmic reticulum (RER), rosettes of ribosomes and numerous polymorphic mitochondria (Fig. 2). Scattered cytoplasmic densities abound within the cytoplasm or are attached to the inner cell surface of the cell membrane or sarcolemma. Another relatively uncommon cell type contains an irregular heterochromatic nucleus, which is surrounded by a small rim of cytoplasm. Neither MFs nor cytoplasmic densities are prominent in this type of cell, which is considered to be a fibroblast. A third type of cell contains numerous dense bodies (probably lysosomes) and is considered to be a wandering macrophage. In the emu, another cell type, the melanocyte, regularly occurs and is filled with melanin granules that are responsible for the dark colouration of the testes of this bird.

\section{Peritubular boundary tissue}

The peritubular boundary tissue of the seminiferous tubules contains alternating layers of collagen fibres and cells that display features of myoid or smooth muscle cells, similar to those described above for the muscle cells in the testicular capsule. Four or five layers of peritubular muscle cells are usually present (range: 2-6 layers; Fig. 3). 


\title{
Immunohistochemistry
}

\author{
Testicular capsule
}

Immunoreaction to actin MFs is slight to strong throughout the testicular capsule of the emu and the ostrich. In the ostrich, strong immunoreaction to actin is largely confined to the outer half of the testicular capsule,with only a few, slightly positive strands of tissue being scattered in the inner half (Fig. 4). This zonal arrangement is reversed in the emu. The tunica adventitia of blood vessels in the testicular capsule is strongly positive for actin in both birds. The testicular capsules of both birds are moderately to strongly immunopositive for desmin IF (Fig. 5). The intensity of desmin immunoreactivities in the emu and ostrich shows speciesspecific zonations similar to those seen in the smooth muscle actin MFs. Only the emu exhibits positive immunoreaction to vimentin IFs. This reaction is uniformly moderate (Fig. 5). Cytokeratin is not immunoexpressed in the testicular capsule of either bird.

\section{Peritubular boundary tissue}

Smooth muscle actin MF immunoreactivity was demonstrated in the peritubular tissue of both birds. Immunostaining for actin was moderate to strong in the ostrich, but very weak to slightly moderate in the emu (Fig. 4).

The peritubular boundary tissue in both birds was also immunopositive for desmin (Fig. 5). Moderate to strong desmin immunoreaction, similar to that seen in the inner zone of the tunica albuginea of the testicular capsule, was demonstrated in the peritubular tissue of the testis of the emu. The peritubular tissue of the testis of the ostrich, however, expressed weak desmin immunoreactivity.

An intense immunopositive vimentin reaction was identified in the peritubular tissue of the testis and in the Sertoli cells of the emu, but not in the ostrich (Fig. 5c). Cytokeratin, however, was absent in both birds.

\section{Discussion}

Histology and ultrastructure

\section{Testicular capsule}

Although the avian testicular capsule is considered to be thin relative to that of the mammal, this study shows that the capsular tissue in ratite birds is considerably thicker than that in other birds, particularly in the members of the Galloanserae that have been studied (Lake 1971; Hodges 1974; Aire and Ozegbe 2007). Aire and Ozegbe (2007) have observed that the thickness of the testicular capsule in the domestic fowl $(81.5 \pm 13.7 \mu \mathrm{m})$ is much higher than that reported for the same species $(30-60 \mu \mathrm{m})$ by Hodges $(1974)$. The thickness of this capsule is much greater in ratites than in members of the Galloanserae (Aire and Ozegbe 2007), by a factor of up to seven-fold for the ostrich, and two-fold for the emu. Data for testicular capsule thickness in mammals are scanty but Arenas et al. (1997) have reported a value of $490.70 \pm 24.5 \mu \mathrm{m}$ for young men and $590.84 \pm 25.9 \mu \mathrm{m}$ for elderly men. The testicular capsule in the ostrich is therefore thicker than that of man and, although the capsule in both ratites is much thicker than that of members of Galloanserae (Aire and Ozegbe 2007), that of the emu is much thinner than that of man. No obvious branching of testicular septa from the testicular capsule has been observed in either bird. Instead, loose connective tissue, distinct from the testicular capsule tissue in both its orientation and composition, conducts blood vessels into the testicular parenchyma (Aire 2007a). The tunica albuginea of the testicular capsule in both the emu and ostrich is different in its arrangement of collagen fibres and smooth muscle cells from that in the Galloanserae (Aire and Ozegbe 2007). In the latter, most of the tunica albuginea comprises smooth muscle cells and few collagen bundles. The ratites are thus similar to mammals (Banks et al. 2006) in having several rows of alternating smooth muscle cells and large bundles of intervening collagen fibres. In the ostrich, in particular, the peritubular smooth muscle cells send thin cytoplasmic processes, in a retiform manner, between bundles of collagen fibres. The 
contraction of the smooth muscle cells and their cytoplasmic processes is capable of activating the entire capsule as a unit, as do the concentrated smooth muscles in the relatively thin testicular capsule of Galloanserae. The differences in testicular capsule thickness between the Galloanserae and Ratitae are probably attributable to the abundance of bundles of collagen fibres in the latter. The role of the preponderant collagen fibres, other than that of providing support for, and conferring tensile strength to, the testicular capsule in the much larger organs of ratites is not clearly understood.

\section{Peritubular tissue}

The composition of the peritubular tissue in the ratite birds studied here is generally similar to that reported for other birds (Rothwell and Tingari 1973; Van Nassauw et al. 1993; Aire 1997; Aire and Ozegbe 2007). The boundary tissue is not understood at present. By virtue of the immunoexpression of the actin and desmin systems in the outer zone of the testicular capsule of the ostrich, this zone is probably the most contractile segment of the capsule, in contradistinction to the situation in the emu, in which the inner zone consistently contains actin, desmin and vimentin. The emu testicular capsule is thinner than that of the ostrich but contains more smooth muscle cells than collagen fibres, and therefore, probably requires the full contractile force of the entire tunica albuginea for the effective expulsion of testicular fluid. The also generally similar to that reported for most mammals, although inter-species differences exist in the amount and distribution of smooth muscle-like cells in mammals. For example, in many rodents and in the dog, only one layer of smooth muscle cells is present, interposed between two connective tissue layers (Leeson and Forman 1981), whereas three or four myoid layers are found in man and monkey (Langford and Heller 1973; Leeson and Cookson 1974). In the domestic fowl, several layers (4-5) of myoid cells, with little or no collagen fibres between them (Aire 2007a, 2007b), run parallel to one another.

\section{Immunohistochemistry}

\section{Testicular capsule}

There are obvious differences between the emu and ostrich with respect to their immunoreaction for various types of IF in the testicular capsule. The significance of these differences is reason that the testicular capsule in the ostrich fails to immunoreact to vimentin is unknown. However, although both the Japanese quail and turkey variably immunoreact for this IF system, neither the domestic fowl nor the duck shows immunoreaction for it, indicating that major differences exist regarding the presence of IFs in the smooth muscle cells of the testicular capsule in birds (Aire and Ozegbe 2007). The differences observed may be attributable to the finding that individual smooth muscle cells are not single entities but behave heterogeneously as a result of their ability differentially to express both contractile and synthetic activities at opposite ends of the spectrum (Banks et al. 2006). Differences in the content and expression of MFs or IFs may also be related to species-specific variations in the extent or degree to which fibroblasts differentiate into smooth muscle cells (BustosObregon and Courot 1974; Leeson and Forman 1981; Wrobel et al. 1979, 1988). Thus, in both the emu and ostrich, the myoid or smooth muscle cells may have attained different levels of cytodifferentiation.

The concurrent immunoexpression, in the testicular capsule, of actin, desmin and vimentin (emu) and actin and desmin (ostrich) is not without parallel in mammals. Certain cells are considered to contain more than one IF system, although the various networks do not overlap (Georgatos 1993).

\section{Peritubular tissue}

A striking dichotomy also occurs in the immunoexpression of MFs or IFs in the peritubular boundary tissue between the two ratite birds. Thus, whereas the ostrich strongly immunoexpresses actin and weakly to moderately expresses desmin but fails to immunoreact for vimentin, the emu, on the other hand,moderately or strongly immunoexpresses actinMFs and desmin and vimentin IFs. These are diametrically opposed and interesting variations that are probably species-specific and may be a reflection of a species-determined degree of 
differentiation of fibroblasts into smooth muscle cells (Bustos- Obregon and Courot 1974; Leeson and Forman 1981; Wrobel et al. 1988), as previously mentioned above. Similarly, the co-expression of different types of IF in the same cells has been referred to above. The coexpression of actin and desmin, considered to be abundant in myoid cells (Maekawa et al. 1991), has also been reported by Schlatt et al. (1993) in the peritubular boundary tissue of the monkey.

\section{Concluding remarks}

The testicular capsule of the emu and ostrich, as typical representatives of ratite birds, is much thicker than that of other birds, such as members of the Galloanserae. The tissue composition of both the testicular capsule and peritubular tissue is similar generally to that of members of the Galloanserae and mammals. Actin MFs and desmin and vimentin IFs are variably immunoexpressed in these two tissue types in both birds, with a clear dichotomy in the peritubular tissue. Thus, taken together with studies of some members of the Galloanserae, avian testes clearly contain a morphological mechanism that is represented partly by the smooth muscle cells of the testicular capsule and peritubular tissue for transporting the testicular fluid, which is usually copious in birds, and its cellular content (Aire $2007 \mathrm{a}, 2007 \mathrm{~b}$ ) from the testis into the excurrent duct system; this mechanism is similar to that found in mammals.

\section{References}

Aire TA (1997) The structure of the interstitial tissue of the active and resting avian testis. Onderstepoort J Vet Res 64:291-299

Aire TA (2007a) Anatomy of the testis and male reproductive tract. In: Jamieson BGM (ed) Reproductive biology and phylogeny of birds. Science Publishers, N.H., USA, pp 37-113 Aire TA (2007b) Spermatogenesis and testicular cycles. In: Jamieson BGM (ed) Reproductive biology and phylogeny of birds. Science Publishers, N.H., USA, pp 279-347

Aire TA, Ozegbe PC (2007) The testicular capsule and the peritubular tissue of birds: morphometry, histology, ultrastructure and immunohistochemistry. J Anat 210:31-40 Arenas MI, Bethencourt FR, Fraile B, Paniagua R (1997) Immunocytochemical and quantitative study of the tunica albuginea testis in young and ageing men. Histochem Cell Biol 107:469- 477

Banks FCL, Knight GE, Calvert RC, Turmaine M, Thompson CS, Mikhalidis DP, Morgan RJ, Burnstock G (2006) Smooth muscle and purinergic contraction of the human, rabbit, rat, and mouse testicular capsule. Biol Reprod 74:473-480

Bustos-Obregon E, Courot M (1974) Ultrastructure of the lamina propria in the ovine seminiferous tubule. Development and some endocrine considerations. Cell Tissue Res 150:481-492

Davis JR, Langford GA, Kirby PJ (1970) The testicular capsule. In: Johnson AD, Gomes R, Vandemark NL (eds) The testis. Development, anatomy and physiology, vol 1. Academic Press, London, pp 281-337

Georgatos SD (1993) Dynamics of intermediate filaments. Recent progress and unanswered questions. FEBS Lett 318:101-107

Hargrove JL, Maclndoe JH, Ellis LC (1977) Testicular contractile cells and sperm transport. Fertil Steril 28:146-1157

Hodges RD (1974) The histology of the fowl. Academic Press, London Holstein AF (1967) Muskulatur und Motilität des Nebenhodens beim Kaninchen. Z Zellforsch 76:498-510

Holstein AF, Weiss C (1967) Ûber die Wirkung der glatten Muskulatur in der Tunica albuginea in Hoden des Kaninchens; Messungen des intersitiellen Druckes. Z Ges Exp Med 142:334337

Lake PE (1971) The male in reproduction. In: Bell DJ, Freeman BM (eds) Physiology and biochemistry of the domestic fowl, vol 3. Academic Press, London, pp 1411-1447

Langford GA, Heller CG (1973) Fine structure of muscle cells of the human testicular capsule: basis of testicular contractions. Science 79:573-575

Leeson TS, Cookson FB (1974) The mammalian testicular capsule and its muscle elements. J Morphol 144:237-254 
Leeson CR, Forman DE (1981) Postnatal development and differentiation of contractile cells within the rabbit testis. J Anat 132:491-511

Maekawa M, Nagano T, Kamimura T, Ishikawa H, Dezawa M (1991) Distribution of actinfilament bundles in myoid cells, Sertoli cells, and tunica albuginea of rat and mouse testes. Cell Tissue Res 266:295-300

Maekawa M, Kamimura K, Nagano T (1996) Peritubular myoid cells in the testis: their structure and function. Arch Histol Cytol 59:1-13

Maretta M, Marettova E (2004) Immunohistochemical demonstration of myoid cells in the testis and its excurrent ducts in the domestic fowl. Br Poult Sci 45:585-589

Middendorff R, Müller D, Mewe M, Mukhopadhyay AK, Holstein AF, Davidoff MS (2002) The tunica albuginea of the human testis is characterized by complex contraction and relaxation activities regulated by cyclic GMP. J Clin Endocrinol Metab 87:3486-3499

Paranko J, Pelliniemi LJ (1992) Differentiation of smooth muscle cells in the fetal rat testis and ovary: localization of alkaline phosphatase, smooth muscle myosin, F-actin, desmin. Cell Tissue Res 268: 521-530

Rothwell B, Tingari MD (1973) The ultrastructure of the boundary tissue of the seminiferous tubule in the testis of the domestic fowl (Gallus domesticus). J Anat 114:321-328

Santamaria L, Reoyo A, Regadera J, Paniagua R (1990) Histochemistry and ultrastructure of nerve fibres and contractile cells in the tunica albuginea of the rat testis. Acta Anat 139:126133

Schlatt S, Weinbauer GF, Arslan M, Nieschlag E (1993) Appearance of $\alpha$-smooth muscle actin in peritubular cells of monkey testes is induced by androgens, modulated by folliclestimulating hormone, and maintained after hormonal withdrawal. J Androl 14:340-350

Steger K, Wrobel K-H (1994) Immunohistochemical demonstration of cytoskeletal proteins in the ovine testis during postnatal development. Anat Embryol 189:521-530

Van Nassauw L, Harrisson F, Callebaut M (1993) Smooth muscle cell in the peritubular tissue of the quail. Eur J Morphol 31: 60-64

Virtanen I, Kalljoki M, Närvänen O, Paranko J, Thornell L-E, Miettinen M, Lehto V-P (1986) Peritubular myoid cells of human and rat testis are smooth muscle cells that contain desmintype intermediate filaments. Anat Rec 215:10-20

Wrobel K-H, Mademann R, Sinowatz F (1979) The lamina propria of the bovine seminiferous tubule. Cell Tissue Res 202:357-377

Wrobel K-H, Dostal S, Schimmer M (1988) Postnatal development of the tubular lamina propria and the intertubular tissue in the bovine testis. Cell Tissue Res 252:639-653 Wrobel K-H, Bickel D, Kujat R (1995) Distribution pattern of F-actin, vimentin and alphatubulin in the bovine testis during postnatal development. Acta Anat 253:263-272

Table 1 Testicular capsule thickness in the ostrich and emu

\begin{tabular}{|lll|}
\hline Capsule region & Ostrich & Emu \\
\hline $\begin{array}{l}\text { Free testicular } \\
\text { Surface }\end{array}$ & $578.1 \pm 73.4 \mu \mathrm{m}$ & $176.2 \pm 57.5 \mu \mathrm{m}$ \\
\hline $\begin{array}{l}\text { Orchido-epididymal } \\
\text { Border }\end{array}$ & $1,215.9 \pm 180.7 \mu \mathrm{m}$ & $305.3 \pm 50.1 \mu \mathrm{m}$ \\
\hline
\end{tabular}




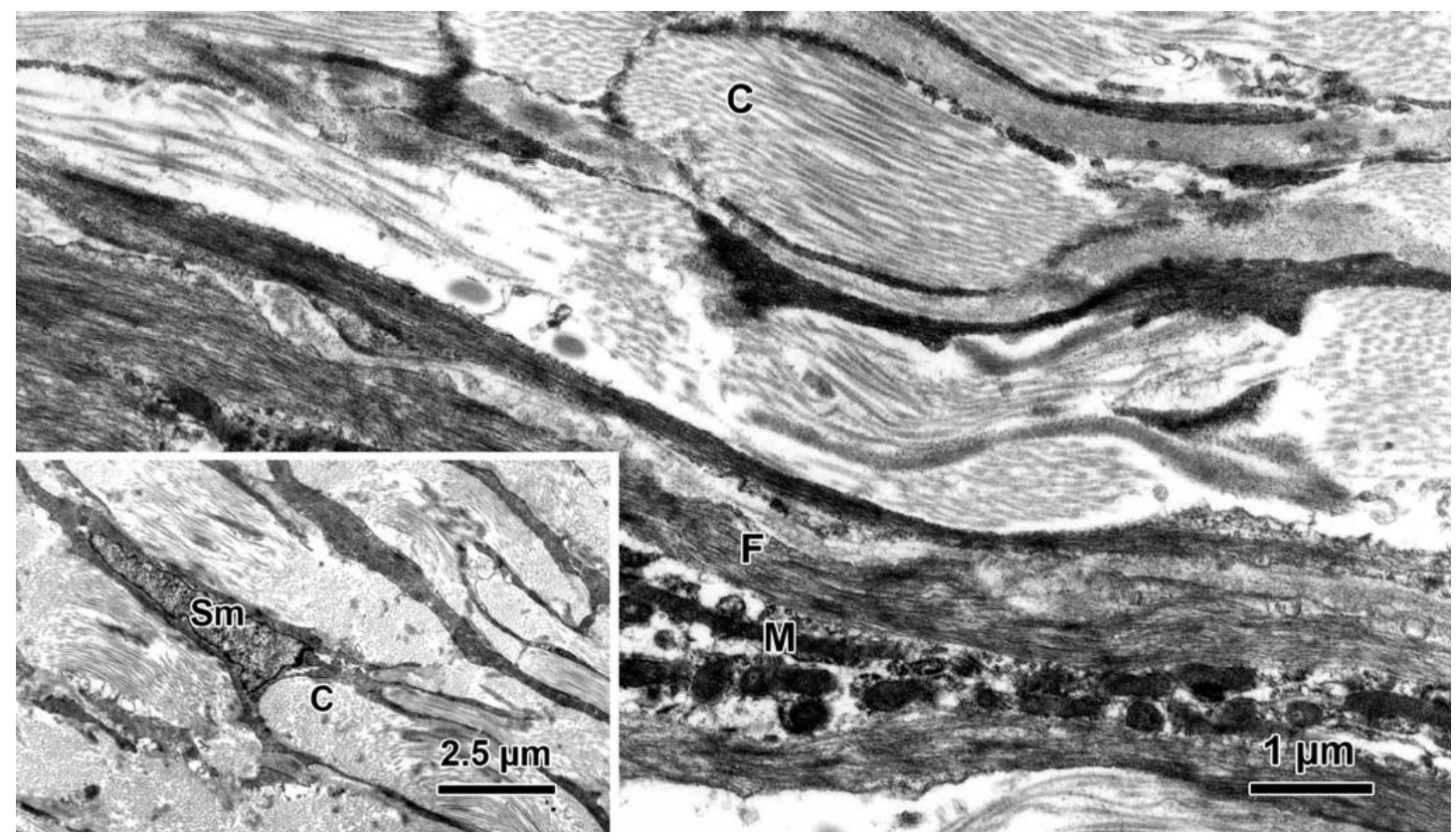

Fig. 1 Electron micrographs of the tunica albuginea of the testicular capsule of the ostrich. Elongated mitochondria (M) and microfilaments $(F)$ are found in the organelle space. Inset: A survey electron micrograph of the tunica albuginea of the ostrich showing a smooth muscle cell $(\mathrm{Sm})$ that has arborized to enclose a bundle of collagen $(\mathrm{C})$

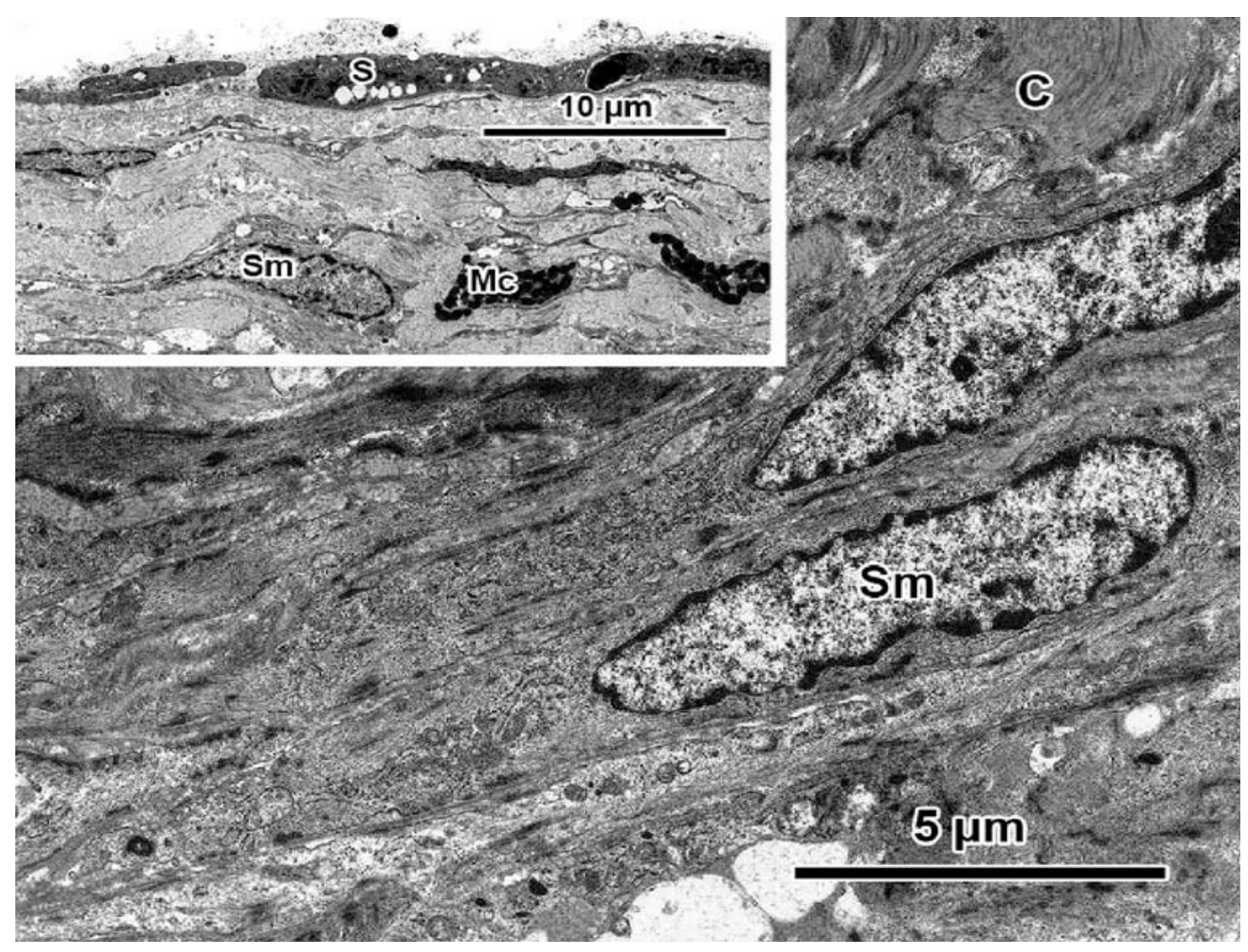

Fig. 2 Ultrastructure of the inner zone of the tunica albuginea of the testicular capsule of the emu ( $S$ squamous cell with a highly elongated and heterochromatic nucleus, Mc melanocyte), showing non-arborized smooth muscle cells $(\mathrm{Sm})$ and collagen bundles $(\mathrm{C})$. Inset: Testicular capsule of the emu showing the tunica serosa and the outer zone of the tunica albuginea 


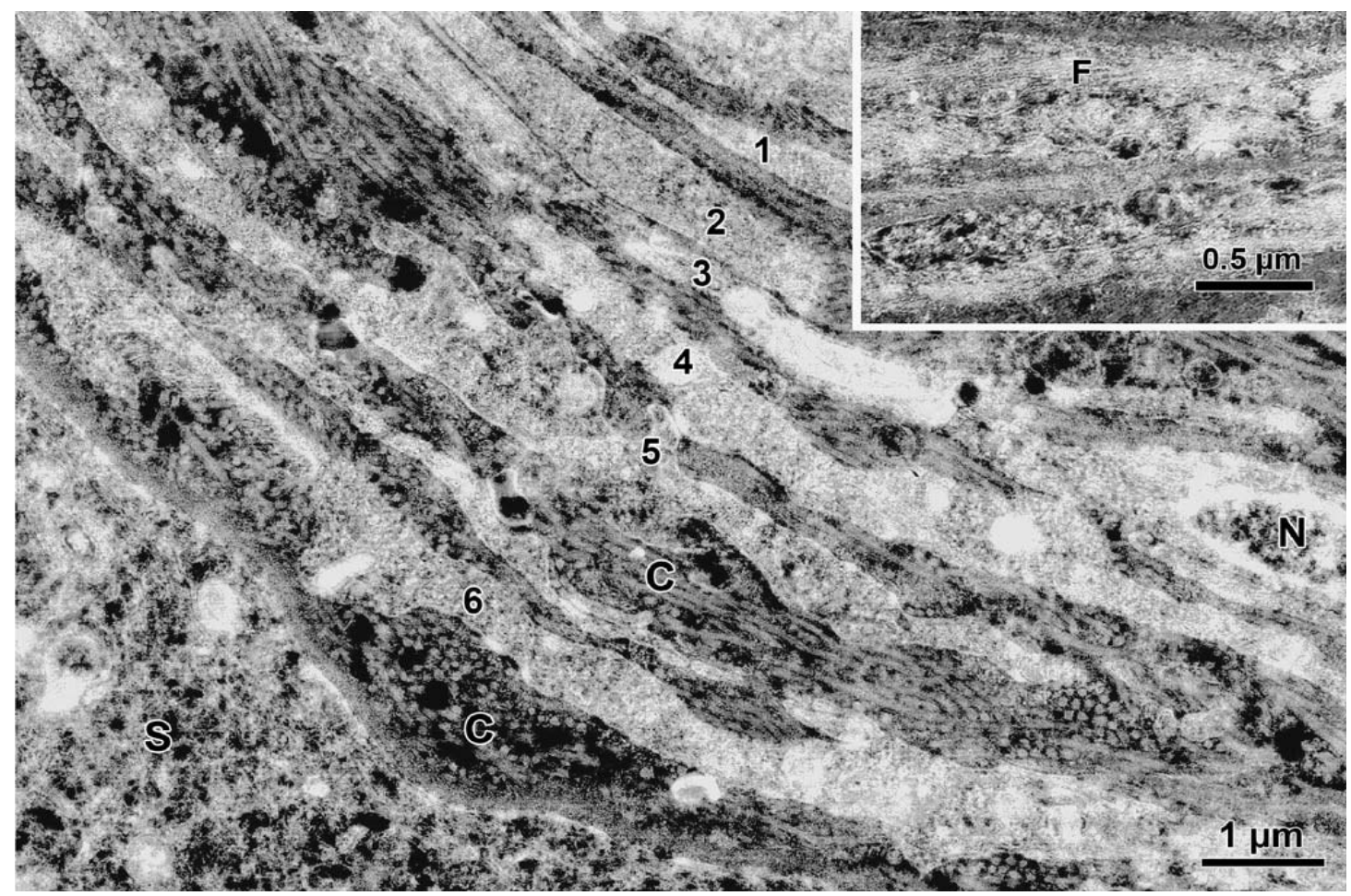

Fig. 3 Ultrastructure of the peritubular tissue of the ostrich displaying several (1-6) layers of myoid cells ( $\mathrm{C}$ collagen fibres, $\mathrm{N}$ nucleus, $\mathrm{S}$ epithelium of a seminiferous tubule). Inset: Peritubular tissue of the emu (F microfilaments)

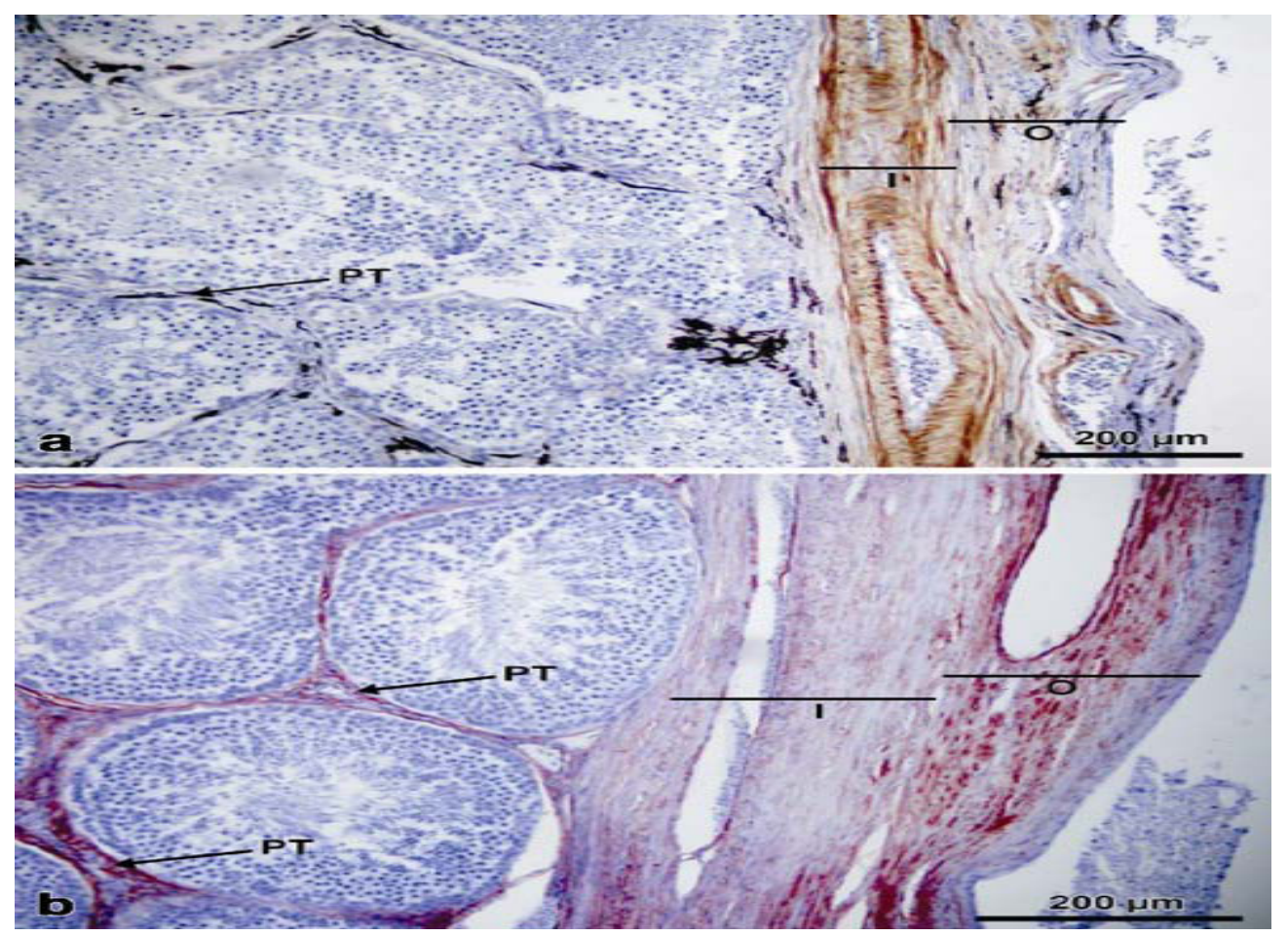

Fig. 4 Micrographs of the testicular capsule and peritubular tissue (PT) of the emu (a) and ostrich (b) immunostained for smooth muscle actin. Strong actin immunoreaction is confined to the inner zone (I) of the testicular capsule in the emu (a) and to the outer zone (O) in the ostrich (b) 


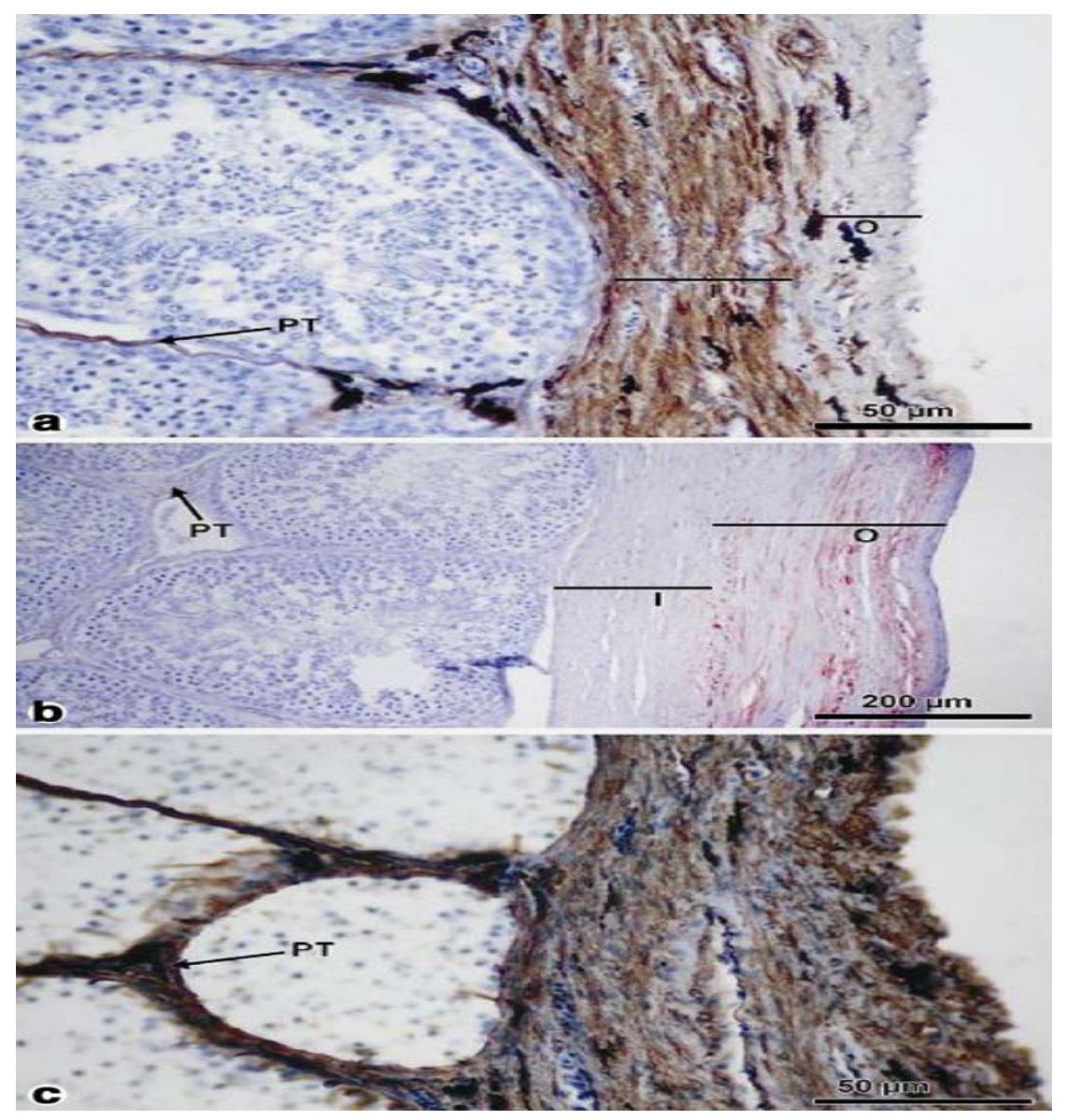

Fig. 5 Testicular capsule and peritubular tissue (PT) of the emu (a, c) and ostrich (b) immunostained for desmin (a,b) and vimentin (c). Strong desmin immunoreaction is confined to the inner zone (I) of the testicular capsule in the emu (a) and the outer zone $(\mathrm{O})$ in the ostrich (b). Vimentin immunopositivity is uniform in the emu (c) 